\title{
Media, Symbolic Violence And Racialized Habitus: Voices FROM Chinese Canadian Youth
}

\author{
DAN CUI \\ FrANK WorRELL
}

\begin{abstract}
This study examines how Chinese Canadian youth perceive media representation of Chinese people and how that perception affects their identity construction. Drawing on Bourdieu and interview data with thirty-six first- and second-generation Chinese Canadian youth in Alberta, we discuss three themes of symbolic violence that Chinese youth experience in the media field. We argue that media-initiated symbolic violence not only reproduces and reinforces racism institutionally and systemically but also contributes to the evolvement of a racialized habitus among Chinese Canadian youth. It affects Chinese Canadian youth's construction of a positive Chinese identity, and at the same time their perceptions as "real" Canadians in the country that they view as home.
\end{abstract}

Keywords: Chinese Canadian youth; Identity; Media; Racialized habitus; Symbolic violence; Racism; Bourdieu; Alberta. 


\section{INTRODUCTION}

To change the world, one has to change the ways of world-making, that is, the vision of the world and the practical operations by which groups are produced and reproduced. (Bourdieu 1989: 23)

M edia as a major social institution play an important role in "worldmaking." The power of the media in constructing common-sense understandings, manufacturing consent, reinforcing racial stereotypes and legitimizing domination has been widely documented in academia (Fleras and Elliot 2007; Henry et al. 2006). Historically, Chinese immigrants have been labelled as the "Yellow Peril", a metaphor that depicts them as a social threat to Western morality and civilization (Anderson 1991). The moral panic instigated by local newspapers contributed to many incidents of racial oppression against Chinese people in North American societies during the late $19^{\text {th }}$ and the early $20^{\text {th }}$ centuries, such as school segregation of Chinese students in Victoria, British Columbia in 1922 (Stanley 2011), mob violence against the Chinese community in Tacoma, California in 1885 (Pfzelzer 2007), and legislative exclusion of Chinese immigrants from Canada (1885-1947) and the United States (1882-1943) (Li 1998). More recently, the moral panic constructed by local media around, for example, the potential threats to national security posed by boats of Chinese refugee claimants in 1999 and the linkage of Asian immigrants with the outbreak of SARS continuously results in a racial backlash against Chinese (Li 2003). Obviously, media outlets play an important role in influencing general public's perceptions, attitudes, and even behaviours towards Chinese people and other racialized minorities.

However, the existing studies on media representation tend to overwhelmingly focus on media discourse itself (Cui and Kelly 2013; Fairclough 2003; van Dijk 1991). Little is known about how racialized minorities perceive media representations and how those perceptions are related to their specific ways of thinking, doing and being. Further, the power of media is usually conceptualized as the function of ideology and hegemony (i.e., as a deliberate and purposive action of propaganda), but contemporary forms of domination may be more insidious in that it solicits social agents' complicity without their recognition (Bourdieu and Wacquant 1992). To this point, Bourdieu's theoretical concepts, such as habitus and symbolic violence, provide important insights in addressing the above concerns through linking the structural with the individual, the macro with the micro, and the subjective with the objective. Drawing 
on Bourdieu, this paper examines the impact of the media on Chinese Canadian youth's identity construction.

In Canada, research on Chinese immigrant youth has yet to be fully developed. This is partly due to the "model minority" discourse that depicts Chinese youth as educationally successful while politically obedient (Lee, 1999; Wang, 2008). Consequently, how these youth struggle as racialized minorities in their everyday lives is often rendered invisible from academic and media attention. Drawing on the Canadian Ethnic Diversity Survey, Reitz and Banerjee (2007) reported that thirty-three percent of the children of Chinese immigrants reported experiencing racial discrimination, and this percentage was second only to that of African Canadians. As a result, children of racialized minority immigrants were reported to have a decreased sense of belonging to Canada. Following up on Reitz and Banerjee's findings, there has been an emerging research interest among Canadian academics in examining ethnic identity, national identity, and sense of belonging among second-generation racialized and ethnic minority youth (Cui 2011). Literature reviews show that a number of researchers argue that youth's ethno-cultural identifications do not undercut or diminish their national identity and attachment to Canada (Jedwab 2008; Wilkinson 2008).

However, most of this type of research simply treats youth's acceptance of Canadian multiculturalism and their self-identification as "Canadian" as a strong indicator of their social belonging to Canada. Racialized and ethnic minority youth may experience racism despite their Canadian identification. More research is needed to explore their racialized experiences in Canada. Thus, this paper focuses on examining how Chinese Canadian youth perceive media representation and racism and the symbolic violence that they experience in the media field. The symbolic violence exercised by the media, we argue, not only reproduces racial inequality institutionally and systemically, but also contributes to the evolution of different forms of racialized habitus among Chinese youth individually. Although the violence is symbolic, its consequence is real (Schubert 2008). It affects the construction of a positive Chinese identity and at the same time self-identification as real Canadians in the country that these youth view as home.

\section{Media Representation and Chinese Immigrants}

The impact of media in maintaining and reproducing social inequalities has been widely documented in academia. Cohen (1963) attributes the power of media to its "agenda-setting" function. Through framing issues, 
media circumscribe the parameters of acceptability and desirability, defend dominant ideology and advance "vested rather than common interests" (Fleras 2003: 303). In other words, media structure the way people experience reality (Grossberg 1996). Social reality and media representation are "mutually constitutive" in that they produce what passes for real, and thus are real in their effects (Fiske 1996; Hall 1997; Thomas and Thomas, 1928). This function of media has a particular implication for racialized minorities, given that the general public relies on media as a crucial source of information about racialized minority communities that are outside their immediate life world.

Fleras (2003) argues that media racism exists in the "foundational principles that govern media values, agendas and priorities"; thus, it is systemic and institutional (283). It is so naturally embedded in the media structure and daily routine operations that the biased representation of minorities is even beyond awareness. Due to the media's central role in constructing core values and belief systems of the dominant society, Henry et al. (2006) point out that if we want to develop effective strategies for fighting racism, we need to direct our attention and efforts to media racism. Canadian media institutions have been criticized for their reluctance to respond to the country's multicultural commitments with their insistent negative representation of minority groups (Henry et al. 2006). Take the Chinese Canadians as an example. Li (1994) examined how media contributed to racializing the issue of "monster houses" built by wealthy Hong Kong immigrants in Vancouver in the 1990s and finally transformed the public debate into a crusade to protect conventional neighbourhoods and the traditional Canadian way of life. Hier and Greenberg (2002) documented how media created a moral panic through sensationalizing the arrival of Chinese migrants along the Vancouver coast in 1999 as posing a threat to Canada's national security.

Cui and Kelly (2013) criticized a "Too Asian?" article published by the Maclean's magazine which blamed some Canadian universities for accepting too many Asian students (see more detailed discussions in later sections). In examining how racialized minority groups consume Canadian English-language TV news programs, Mahtani (2008) reported that Chinese focus groups identified biased news coverage surrounding SARS and the Beijing Olympic bid, which assumed an Anglocentric audience rather than taking their consumer needs into consideration. Compared with the abundant cultural studies that explore media representation of African diaspora communities (Hall 1997; Kelly 1998), research on Chinese people and media is very limited. In this regard, this paper will contribute to the existing literature by uncovering how 
Chinese youth perceive media representations and how their perceptions affect their identity construction in Canadian society.

\section{Media as a Symbolic System and Field: A Bourdieusian Perspective}

Bourdieu's (1977) theoretical framework (e.g., theory of practice) has been widely used to analyse social and cultural reproduction of class inequalities and power hierarchy in the educational field (Lareau, Evans \& Yee 2016; Lehmann 2012). However, it is also possible to use Bourdieu's theoretical concepts to study gender (Reay, 2002), race (Cui 2015, 2017a; Wallace, 2017), and social inequalities in other fields, such as media, which acts as a symbolic system with symbolic power. In theorizing symbolic power, Bourdieu (1991) identified three functions of symbolic systems. First, as an instrument for knowing, symbolic systems are "structuring structures". They construct the objective world through symbolic forms (e.g. binary categories, such as us/them), which are arbitrary and socially determined. Second, as an instrument of communication, symbolic systems are "structured structures". They relate to the deep structures of the social world and serve the function of social integration - "they make it possible for there to be a consensus on the meaning of social world, a consensus which contributes fundamentally to the reproduction of social order" (166). Finally, as an instrument of domination, symbolic systems serve to establish distinction between different groups, legitimize social hierarchies and reinforce unequal power relations between the dominant and the dominated.

The media, in this sense, best demonstrate the three functions of the symbolic system, particularly through their symbolic power of "making things (e.g. groups) with words" (Bourdieu 1989: 23). Symbolic power, according to Bourdieu (1991), is the "power of constituting the given through utterances, of making people see and believe, of confirming or transforming the vision of the world and, thereby action on the world and thus the world itself" (170). As a "magical power", its effect of mobilization is equivalent to that obtained through physical or economic force (170). The contemporary form of domination, for Bourdieu, is more characterized by symbolic domination or symbolic violence than coercion or hegemony (Bourdieu and Wacquant 1992). As Bourdieu (1989: 21) argues, 
Legitimation of the social world is not, as some believe, the product of a deliberate and purposive action of propaganda or symbolic imposition; it results, rather, from the fact that agents apply to the objective structures of the social world structures of perception and appreciation which are issued out of these very structures and which tend to picture the world as evident.

In other words, social agents internalize the social structures as habitus, a system of schemes of perception and appreciation, which takes the dominant classification and the social order based on that as natural and legitimate. With the "fit" between social agents' cognitive structures and the dominant social structure that the media represent, domination and violence is not perceived as such. Thus, symbolic violence, briefly defined, is the violence that is exercised upon social agents due to the function of their habitus. With the concept of symbolic violence, Bourdieu theorizes a "much more powerful and insidious" way that a symbolic system, such as media, maintains domination; comparable to Gramsci's (1971) concept of hegemony (e.g. as a deliberate and purposive action of propaganda) (Bourdieu and Wacquant 1992: 168).

Further, media can also be perceived as a field of power or a force/ competition field that "contains people who dominate and people who are dominated" (Bourdieu 1998: 40). The volumes and types of capital that social agents (e.g., individuals, groups) possess determine their access to as well as their positions within the field. A field may value particular forms of capital while rejecting others, depending on the internal rules of that field (Bourdieu 1990). Those who occupy the dominant position of the field have symbolic power to influence the rules of the field, to legitimize their actions and to perpetuate the structures of the field. Habitus, which is a system of durable dispositions, is structured by social agents' past experiences and in turn, is structuring their present and future practices (Bourdieu 1977). Habitus and fields have a relationship of mutual constitution. Bourdieu's theoretical concepts provide us with a unique perspective in analysing the influence of media on the identification of Chinese youth.

\section{The STudy}

This article draws on data from a research project that explores how Chinese Canadian youth construct identities and negotiate a sense of belonging in Canada. Grounded theory was employed as the main research methodology for its bottom-up approach, which emphasizes that theoretical understanding should be derived from empirical data (Charmaz 
2005). The sampling strategies consisted of maximum variation sampling, snowball sampling and theoretical sampling. Maximum variation sampling was used to ensure a representation of participants from diverse backgrounds (Patton 2002). Snowball sampling was used to reach key informants. Theoretical sampling was used for theoretical elaboration and refinement when initial categories emerged (Morse 2007). Recruitment flyers were distributed to several local Chinese community organisations, two local university campuses (e.g. University of Alberta and University of Calgary) and a popular local Chinese website in Edmonton and Calgary, Alberta.

The sample used in this study included thirty-five Chinese Canadian youth aged between fifteen and twenty-four years old ${ }^{1}$. Eighteen of the participants were males and seventeen were females. A total of twenty participants' parents came from mainland China, ten from Hong Kong and one from Taiwan. Except for a few participants who are in senior high school, the majority are university students from a wide range of faculties. Their parents' occupations range from university professors, business professionals, engineers and technicians to bus drivers, restaurant cooks and housekeepers; some of their parents are unemployed. After ethics approval and initial contact, participants agreed to come to the first author's office located on the campus of the University of Alberta for a 1-1.5 hour face-to-face interview. Prior to interviews, they were required to complete a survey questionnaire that collected their demographic information such as age, gender, place of birth, length of stay in Canada, and family background, etc.

During the interviews, participants were asked to talk about the factors affecting their identity construction at school (Cui 2015, 2017a), within the family (Cui 2017b), and through their formative contact with Canadian mainstream media. Particularly, with regard to media, they were asked to describe what they think of the mainstream media's representation of Chinese people, and how such media representation affects them in the ways that they perceive who they are or are not. After each interview, the demographic information of participants was immediately entered into an excel spreadsheet and each was assigned with a pseudonym. Interview data were transcribed verbatim. Data analysis began simultaneously with data collection. After initial data analysis,

1. The original sample includes 36 participants. World Health Organization defines youth as 15-24 years ("Recognizing Adolescence", WTO). So the final sample used in this paper consists of 35 youth (aged 15-24) with one participant aged 25 excluded (who exceeds the age limit of youth definition). With little relevant information on media, the exclusion of this participant does not affect the findings of this paper. 
further data were collected through theoretical sampling to refine tentative categories (Charmaz 2006). All the interview transcripts, codes and memos were organized and managed through qualitative data analysis software, Atlas-Ti.

\section{Absence, "Presence", and Silence}

To exist socially means also to be perceived, and perceived as distinct. (Bourdieu 1984: 224)

Matt has lived in Canada for eighteen years since the age of two. When asked how he perceived media representation of Chinese people, he identified the issue of the lack of Chinese reporters in news programs and the lack of Chinese role models in the media with whom he could identify.

I don't really see Chinese reporters. There are not many Chinese Canadian broadcasters for one station. There is one, but she doesn't do the local news or national news, she does entertainment. She is an entertainment reporter. You mainly see Caucasian people. I say local TV and media do not have much influence, but because of the Internet, you have more exposure to Chinese culture. One of my role models is a famous Chinese badminton player, Lin Dan. I wouldn't know him without the internet; local media doesn't help Chinese identify at all.

Henry et al. (2006) once reported the problem of invisibility of people of colour in Canadian media. They noted that the unequal status of racialized minorities in media was reflected by "their absence from on-air roles, such as anchors, reporters, experts, or actors, and their lack of representation at all levels of staffing operations, production, and decisionmaking positions in communications" (255).

In addition, in a study that examined the appearance of racialized minorities in national evening news programs, researchers found that minority people were often cited as representatives of their own racial or ethnic communities rather than representing Canadian public opinion on some general topics (Perigoe and Lazar 1992, as cited by Henry et al. 2006). Therefore, Henry et al. (2006) argue that although in theory media institutions are expected to recruit people from diverse backgrounds and reflect alternative viewpoints, in reality, racialized minorities are often excluded or marginalized in traditional print media representations (with some few exceptions, such as CBC News). 
To have a diverse representation of staff in the media field is important because facts do not directly turn themselves into news; rather, it is the journalists' selection and interpretations of these facts that determine which facts are newsworthy and how to represent them in order to reflect a particular version of reality (Ericson et al. 1991). In other words, media staff play a significant role in filtering information, reconstructing knowledge, and consequently framing social order in the sense that they may not intentionally distort reality but as an inadvertent consequence through their racialized beliefs and attitudes towards "Others".

The "absence" of Chinese people in the media has been further compounded by their "inauthentic presence", as characterized by Hollywood movies, where Chinese people are often depicted as either historical figures hundreds of years ago or stereotyped Kung Fu masters with exotic martial arts skills. As Said (1978) poignantly argues, "The Orient was Orientalized not only because it was discovered to be "Oriental" in all those ways considered common place by an average nineteenth-century European, but also because it could be - that is, submitted to beingmade Oriental" (6). Neither of these representations has any relevance to the reality of Chinese people in contemporary societies in which Chinese youth could relate to or "see themselves". Richard, a 23-year-old university student who has lived in Canada for twelve years raised this point:

Most of the movies in Canada are produced in Hollywood and in the States, and most of them don't have a lot of representation of visible minorities in terms of Chinese ... Some of the older movies I've seen depict Chinese people as more like the Qing dynasty. That's not happening anymore. The latest I can think of that had some Chinese representation had Jet Li in it; but that was a fictional period piece...the Dragon Emperor so that isn't really depicted as how Chinese people are being represented in the media.

The absence of Chinese people in Hollywood movies was also evidenced by the recent success of Warner Bros' "Crazy Rich Asians". Time magazine used the title "Crazy Rich Asians Is Going to Change Hollywood. It's About Time" (Ho 2018) to highlight its significance as a major step forward in the media field for representation of Asian people. As Ho (2018) argues, "for decades, Asian Americans working in the film and television industry have carried the impossible burden of fixing a system that has tended to punish, stereotype and ignore them". This movie is the first modern story with an all-Asian cast and an Asian-American lead since The Joy Luck Club in 1993. It was said that an early prospective producer suggested casting a white woman as the lead to cater to the taste of Western audiences (Elizabeth 2018; Sun 2015). Although 
this suggestion was not enacted, it is interesting to see that a biracial (British-Malaysian) actor, Henry Golding, was cast as the movie's lead male character, rather than a fully ethnic Chinese actor. Moreover, the movie is exotic and mysterious, highlighting the luxurious living style of a lavishly wealthy Singapore Chinese family that attracts Western eyes, rather than an authentic representation of common Chinese people in their everyday life.

As Richardson (2007) argues, "it is also important to recognize that textual or journalistic meaning is communicated as much by absence as by presence; as much by what is 'missing' or excluded as by what is remembered and present" (93). Through making some groups absent while others are present along racial lines, media legitimizes the rules of a game that is based on racial hierarchy. Whiteness becomes a critical symbolic capital that is highly valued by the field. Symbolic capital, according to Bourdieu (1990), is "the denied capital", which is recognized as legitimate but misrecognized as capital (118). Lacking the valued symbolic capital, Chinese people are either denied entrance into the field or subjugated to a marginalized position within the field. Through manipulating social agents' relative positions within the field, the media reinforces group boundaries.

According to Bourdieu (1989), groups should never be perceived as real groups with fixed essence; rather, they are social relations that depend on social agents' relative positions in the social space. As he argues,

...social space is so constructed that agents who occupy similar or neighboring positions are placed in similar conditions and subjected to similar conditionings, and therefore have every chance of having similar dispositions and interests, and thus of producing practices that are themselves similar. (17)

To this point, the absence and presence in the symbolic space also frame social agents" "sense of one's place" in that they construct a group identity based on their relative positions and develop corresponding social dispositions in adjusting to the positions that they are allocated. For Bourdieu (1989),

It is this sense of one's place which, in interactions, leads people whom we call in French 'les gens modestes,' 'common folks,' to keep to their common place, and the others to 'keep their distance,' to 'maintain their rank', and to 'not get familiar.'(17)

In this sense, the absence and the presence of minority people in the media field should be conceptualized as more than an issue of under-representation; rather, it is related to the evolvement of a racialized habitus. 
As Bourdieu argues, "social distances are inscribed in bodies or, more precisely, into the relation to the body" (17). Particularly for some Canadian Chinese youth, in adapting to their marginalized positions in the media field, they realize they are not treated as real Canadians and thus do not belong to the "imagined community" of Canada (Anderson 1983). For Matt, such perception results in the development of a kind of racialized habitus, which is characterized as a sense of embarrassment and low self-esteem associated with an inferior Chinese identity. This can be seen in Matt's narratives about his identity change brought about by the 2008 Beijing Olympics. This event puts Chinese people under the spotlight of world media. From being absent to truly present and from the marginalized to the highlighted, this event greatly boosted Matt's self-confidence as a person of Chinese origin. As he reflected,

I was proud that, during the Olympics, China was pretty amazing. They pretty much have the most medals; they have the best athletes, even in badminton. At that time, I was proud to be Chinese, not ashamed.

It is worthwhile to note that social agents' racialized habitus can assume different forms. Among thirty-five participants, only Matt and Richard identified the problem of absence and inauthentic presence of Chinese people, while the rest of the participants did not even raise it as an issue, thereby allowing the reproduction of racial inequality go unchallenged. Consequently, we argue that Chinese youth' racialized habitus is also manifested as a kind of silence. Their silence either indicates a takenfor-granted assumption that accepts the absence/inauthentic presence as normal or a sense of disengagement due to a "feel" of impossibility to change the status quo. Therefore, these Chinese youth's racialized habitus is characterized either as "misrecognition" of symbolic domination (e.g., that accepts the absence as normal) or as a political inertia. No matter what it is, however, symbolic violence results and racial inequalities are maintained. As Bourdieu (1998: 8) argues,

The world shown by television is one that lies beyond the grasp of ordinary individuals. Linked to this is the impression that politics is for professionals, a bit like high-level competitive sports with their split between athletes and spectators. Especially among those who are basically apolitical, this worldview fosters fatalism and disengagement, which obviously favors the status quo. 


\section{Racializing The Body}

What is at stake in the struggles about the meaning of the social world is power over the classificatory schemes and systems which are the basis of the representations of the groups and therefore of their mobilization and demobilization... (Bourdieu 1984: 479)

In describing the media representation of Chinese people, Lily, a Chinese girl in Grade 11 who immigrated to Canada at the age of 16, told me a popular racial joke that targets Asian/Chinese bodies: "How do you blindfold an Asian/Chinese?" The answer is "with dental floss". During the interviews, the concerns over their ways of looking and talking, such as eye shape and accent, became a recurring theme in the narratives of Chinese youth about their identity struggles. As Sandra, a Canadianborn-Chinese university student stated:

What are the stereotypes in the media? ... that is our eyes are slitty because they always draw cartoons. All the cartoons have those eyes, and then you say, that's an Asian there. They accentuate the shape of our eyes...

This point was echoed by Ming, who immigrated to Canada at the age of seven and has lived here for thirteen years: "If you look at TV shows, like Family Guy or the Simpsons, they are obviously going to portray foreigners as having a funny accent and slanted eyes, and a choppy way of talking". Xiaobo, a Canadian-born-Chinese university student, further critiqued how Asian body features were exaggerated by TV shows, such as Family Guy, for the purpose of entertainment.

There's a cartoon called Family Guy, and there's this one character that's an Asian female. She's Japanese though; she's a news reporter, and they draw her like this [imitating her eye shape]. Then every time she reports, every time on the news story, they'll say Siazi Okazowa has a news story. Siazi Okazowa is our Asian reporter. They kind of mention it. I don't know why that's funny. I don't think it's funny. Then it goes to her and then she has funny eyes, and then she'll kind of have a little bit of an accent (emphasized by participant).

Being ridiculed as weird and funny, these racialized body features such as eye shape, have a significant implication for the self-esteem and identity construction of Asian minority youth. A CNN report best demonstrates this point. In quoting a twelve-year-old girl, Min-kyong, the report emphasizes that it is the girl's "Asian eyes" that causes her lack of confidence about her body image, and plastic surgery will give her a "Western look" that helps her regain confidence (CNN: May 23 2011). 
'If I get the surgery, my eyes will look bigger,' explains Min-kyong. Everyone, she says, points out her small eyes. It's why she doesn't think she's a pretty girl. A surgery which cuts a fold into her eyelid to create a double fold will widen her eyes. The effect will also be to give her a slightly more western look.

The CNN report claims that more and more Asians conduct plastic surgery in order to seek a "Western look" because the definition of beauty is not based on the standard Asian face, but closer to a Caucasian face. In Western media discourses, an aesthetic standard assumes a Western look as the norm and a hierarchical classification (Western vs. Asian) based on that seems so naturally justified that it becomes a commonsense understanding without any questioning.

However, according to Bourdieu (1991), "the most 'natural' classifications are based on characteristics which are not in the slightest respect natural and which are to a great extent the product of arbitrary imposition" (222). The dominant cultural standards of any social order are fundamentally arbitrary in that they are products of previous power struggles over "legitimate delimitation" (222). Therefore, there are no such universal standards, values and beliefs that are beyond any social influence (Swartz 1997). Media, as a symbolic system, has symbolic power of "making things with words", which is "a power of consecration or revelation" (Bourdieu 1989: 23). In other words, the seemingly "natural" classification and its associated connotations, such as Asian eyes (small, funny, ugly) vs. Western eyes (big, normal, beautiful), "begin to exist only when it is selected and designated as such" (23). Thus, behind "their apparent neutrality", these "ethnical, aesthetic, psychiatric or forensic classification[s] that are produced by the "institutional science"" serve some social and ideological function (Bourdieu 1984: 477).

The classification characterized by binary oppositions (e.g., Asian vs. Western), as Bourdieu argues, is closely linked to "the most fundamental oppositions within the social order: the opposition between the dominant and the dominated" (469). In this sense, through its classification schemes, the media work to establish a distinction between groups, legitimate racial hierarchy and reinforce domination. And ethnic identity struggle, for Bourdieu, is "a particular case of the different struggles over classification" (1991, 221). It is a struggle over "the properties (stigmata or emblems)" and "its associated durable marks, such as accent" and eyes. 
[It is] struggles over the monopoly of the power to make people see and believe, to get them to know and recognize, to impose the legitimate definition of the divisions of the social world and, thereby to make and unmake group. What is at stake here is the power of imposing a vision of the social world through principles of di-vision which, when they are imposed on the whole group, establish meaning and a consensus about meaning, and in particular about the identity and unity of the group, which creates the reality of the unity and the identity of the group (211).

Particularly, through making a classification that stigmatizes Chinese people's way of looking and talking, the media produce a racialized Chinese identity with negative connotations of inferiority, abnormality and undesirability. At the same time, these racialized body features become devalued symbolic capital, which may disadvantage Chinese youth in the field of competition, particularly given that social agents' symbolic capital and economic capital can be exchangeable and convertible (Bourdieu 1991). To acquire a "Western look" means to accumulate a valued symbolic capital based on the "rules of the game". The remarks from Min-Kyong's mother in the CNN report best illustrates this point,

Her mother, Jang Hyu-hee, says her daughter didn't ask for the surgery. 'I'm having her do it,' says Jang, 'because I think it'll help her. This is a society where you have to be pretty to get ahead. She's my only daughter.'

(CNN: May 23 2011)

It seems that Min-Kyong's mother understands "symbolic capital is credit", "a kind of advance", which could be converted into other forms of capitals and benefit her daughter in mobilizing a higher position in the power hierarchy in the future (Bourdieu 1989: 23).

Although the CNN news is contextualized in the United States, it has been argued that Canadian minority youth sometimes share concerns similar to their American counterparts in negotiating a racialized identity (Kelly 1998). For example, some participants in our study expressed a desire to acquire highly valued symbolic capital based on the dominant classification schemes (e.g., to have bigger eyes). In doing so, they develop a racialized habitus that accepts Western aesthetic classification and standard as the norm without challenging its legitimacy. There are other participants, such as Xiaobo, who indicated that highlighting Asians' racialized body features made him feel uncomfortable (e.g., I don't know why that's funny. I don't think it's funny). However, he later added that such racial stereotypes may apply to some Chinese but not to all. In this point, Xiaobo exemplified a racialized habitus which is characteristic of a partial resistance against media racism by questioning its 
over generalization but without interrogating its underlying assumptions and the norm itself.

In trying to prove "there are indeed others to whom this [racial stigma] applies, but it does not apply to me", some participants unwittingly internalize and reproduce the oppression based on race (Pyke and Dang 2003 , as cited by Cui 2015, 1164). In both cases, media exercised a symbolic violence without or with their limited recognition (Bourdieu and Wacquant 1992). More specifically, in accepting the dominant classification and standard as legitimate and framing their actions or desires based on that, these Chinese youth are subject to media-initiated symbolic violence with their own complicity. Although Xiaobo demonstrates a partial critical consciousness by voicing some critiques, his ambiguous attitudes towards the Western "norm" illustrate the complex nature of one's racialized habitus, which is not fixed but characteristic of ongoing conflicts, construction, reconstruction and transformation.

\section{Being a Social Threat}

The news, the incidents and accidents of everyday life, can be loaded with political or ethnic significance liable to unleash strong, often negative feelings, such as racism, chauvinism, the fear-hatred of the foreigner or xenophobia. (Bourdieu 1998: 21)

Historically, Chinese immigrants have been described as a social threat to Western morality and civilization, evident in the "Yellow Peril" metaphor (Anderson 1991). Although the days when Chinese people were treated as the Yellow Peril have passed, the media-constructed anxiety that perceives the Chinese as a social threat to the well-being of "real" Canadians has not; rather, it has been modified with new content and forms.

In particular, Chinese people are often represented as "foreign competitors/invaders", who come to grab limited social resources from local people. For example, Maclean's, a Canadian leading newsmagazine, published a provocative article "Too Asian?" in November 2010 (Findlay and Köhler 2010) which blamed Asian students for taking away postsecondary educational opportunities from White students. Specifically, it quoted a White mother who complained that the reason her son was not accepted by university was because Asian students were taking up university spots. The publication of the "Too Asian?" article occurs in the later stage of data collection. So the rest of the participants (around ten of them) were asked to read the article in advance and voiced their opinions 
during the interview. Interestingly, some agreed with this article's premise that there is a too large proportion of Asian students at the University of Toronto and the University of British Columbia, instead of providing any critiques of its racist assumptions. Others, such as Qiao, a Hong Kong immigrant youth who came to Canada at the age of 14, refuted the competitor discourse constructed by the "Too Asian?" article. He pointed out that many newcomer Chinese immigrant youth were actually in a disadvantaged position in applying to university due to language barriers. As he noted,

One thing they have to keep in mind is that a lot of Chinese people, before coming to Canada, they didn't even know a word in English, ok. Like me, when I first came, I was standing in front of McDonald's, and I was trying to order something, and I looked at the picture and I didn't know a word in English. How did I make it to university at the same time? Because I spent triple the amount of time in studying, in looking through the dictionary, until this got ripped. I spent triple the amount of time learning a language that I'm not even familiar with...you know, they [the media] are denying your effort.

By simplistically reducing the complicated factors that affect one's postsecondary opportunity to a racial issue, the competitor discourse exemplified in the "Too Asian?" article aims to restrict Asian/Chinese students' university access and accordingly their social mobility and life chances based on educational credentials in the long run (Cui and Kelly 2013). Regarding the symbolic violence of media, some Chinese youth, however, responded with a kind of non-recognition due to their internalized racist social structures, or racialized habitus, whereas others demonstrated agency as a critical consciousness and resistance against media racism.

The interviews were conducted in the years 2010-2012, not too far distant from the first time that China hosted the Summer Olympics in 2008. Therefore, many participants mentioned the 2008 Beijing Olympics regarding media representation of China and Chinese people either positively (e.g., China winning gold medals made them feel proud of their Chinese origin) or negatively (e.g., the social threat discourse). Particularly, this event not only garnered China compliments and recognition across the world but also triggered some Western media's anxiety about China as a potential threat to the dominant positions in the global power hierarchy. Liang, a 19-year-old university student who immigrated to Canada from mainland China at the age of nine, mentioned an episode in South Park entitled "The China Problem", which aired in 2008. This episode described how one of its main characters, Cartman, after watching 
the opening ceremony of Beijing Olympics on television, began to suspect that the Chinese would invade America (Olympic Nightmare: http:// southpark.cc.com/clips/187263/olympic-nightmare). Liang recalled that his friends began to pick on him after watching the South Park episode.

Well, they [his friends] understand Chinese culture as being what they watch on TV, right? And then they watch South Park. There was an episode about Chinese people and the Olympics and how they are going to take over the world, and they joke about that a lot... Making fun of the Olympics and how there were a lot of people and all the Chinese immigrants coming to North America have a plan of multiplying and taking over America.

As Park (2011) argues, Asian countries today are recognized for their rising economic and political power, but at the same time "represent a threat to the national and global world order to an extent that other racialized minorities and non-Western regions do not" (647). The Western media's hostile attitudes towards China are also reflected by some media commentators' biased critiques of Chinese athletics, which either disparage their aspirations to win gold medals or attributes their excellent performance to unethical training. As Fang, a 17-year-old Canadianborn-Chinese girl noted,

I don't think I really like the Chinese in terms of their strong emphasis on being the best in the world, and you know in the Olympics they choose the best athletes. They start training them from six or four years old or something, stuff like that or, for example, that half pipe snowboarder yesterday, the first one to run. He was sixteen or something, and he only goes in it because he had gymnastics or martial arts training and he's just been trained to do well in the Olympics. I have a feeling that those kinds of values, wanting to be seen as number one, for example, and then, well obviously there's nothing wrong with that, but going to the extent of taking... stripping away a child's childhood and making them learn skills that they may or may not actually personally enjoy as much and then making them represent the country. I don't think those are good values to bring up your children with.

When asked where she got this kind of information, Fang replied: "the news on the Olympic channel. They'll tell you the background of most of the athletes. I know from gymnastics, a lot of them are really, really young". Due to such negative media representation of China, Fang noted that she did not want to be identified as Chinese. In challenging and decolonizing Western dominant perspectives and biased critiques against China (Cui, 2017a), we need to critically reflect on the following questions. How do these media commentators know that Chinese athletes 
do not enjoy their training or are forced to do what they do not really like? On what basis do they draw the conclusion that being committed to sports training equals being deprived of one's childhood? From whose perspective did the media make such judgments and to serve whose interests?

As Bourdieu (1998) argues, "when commentators spew ethnocentric or racist contempt, the journalistic evocation of the world does not serve to mobilize or politicize; on the contrary, it only increases xenophobic fears" (8). In interrogating the irresponsible way that media deliver socalled information that allegedly reflects reality, Bourdieu (1998: 20) offers a sharp critique:

Sometimes I want to go back over every word the television news-people use, often without thinking and with no idea of the difficulty and the seriousness of the subjects they are talking or the responsibilities they assume by talking about them in front of the thousands of people who watch the news without understanding what they see and without understanding that they don't understand. Because these words do things, they make things they create phantasms, fears, and phobias, or simply false representation.

Similar to Fang, Linda, a Hong Kong immigrant descendant who has lived in Canada for 15 years since the age of six revealed that the negative media representation of China and the Chinese people made her "not want to be associated with it [Chinese identity]". In accepting the legitimacy of devalued cultural capital assessed by the media, Fang and Linda are subject to media-initiated symbolic violence, consequently reproducing a belief in their own racial inferiority. Particularly, Fang's and Linda's racialized habitus can be characterized as an avoidance from and a critique of the Chinese communities where they come from "through the sense of incompetence, failure or cultural unworthiness" (Bourdieu 1984: 386).

\section{Conclusion}

Chinese Canadian youth are labelled as a model minority, whose struggles as racialized minorities in North American societies are often rendered invisible from academic attention. This paper examines the role that the media play in reproducing racial inequality and influencing Chinese youth' identification. Particularly, three themes identified by Chinese Canadian youth are discussed, including the issues of "absence/inauthentic presence", racialized body, and social-threat discourses. These themes demonstrate that symbolic violence as a particular insidious form of violence is "everywhere and nowhere" (Bourdieu and Eagleton 1992, 
as cited by Schubert 2008: 195). It is everywhere because the classification schemes and systems, the highly valued symbolic capital, logic of practice, rules of the game, acceptable discourses and reasonable behaviours are not just unique to the media field but are homologous to other fields as well. Take the educational field as an example (Cui 2017a). Michael, a grade 10 student who left mainland China at the age of eight, revealed that the social-threat discourse also appeared in a biology class. He recalled that his biology teacher made an analogy between immigrants and herbivores by suggesting that "with all the immigrants coming in... they have more kids, we will run out of supplies; so the end of the world".

Similarly, the symbolic violence that treats the Western White appearance as normative and superior, while derogatively racializing Asian eyes, does not only happen in the media field but is also homologous to the educational field as well. For example, Lily described a frustrating question in her grade 10 test, where students were asked to explain why Asian people are enthusiastic about cosmetic surgery, such as making eyes bigger and noses longer. The correct answer was 'Westernization'. Feeling offended, Lily argued against such racist school knowledge construction: "Because we have a different aesthetic value from Western people. How come they interpret the way we seek beauty as a desire to be Westernized?" (Cui 2017a, 1158). To fully understand symbolic violence requires us to conceptualize it in the homology of the fields. Social agents situate themselves in more than one social field, which can be conceptualized as one common social space - the field of power (Thomson 2008). Symbolic violence is everywhere because it is deeply embedded in the field of power as "an effective and efficient form of domination in that members of the dominant classes need exert little energy to maintain their dominance" (Schubert 2008: 184).

Symbolic violence is also nowhere because it is gentler and subtler than other forms of violence, thus more difficult to identify and resist (Schubert 2008). Symbolic violence may take a form of humour in which racist discourses are justified in a burst of laughter. We argue that our participants do not recognize its existence when they use the categories that benefit the dominant groups to understand the world, evaluate their strength and weakness, and frame their actions. Symbolic violence occurs when they desire to have bigger eyes and speak English without "accents", when they believe in the inferiority of their ethnic cultural heritage, and when they experience anxiety, embarrassment and lowconfidence due to a failure to conform to the norm. However, it is important to note that the Chinese Canadian youth in our study responded to symbolic violence in different ways. Some did challenge the status 
quo by arguing against the specific vision of reality imposed by the media, whereas others took the media-constructed distinction as natural and legitimate.

The function of symbolic violence depends on the social agents' habitus. The majority of Chinese youth in this particular study developed a racialized habitus which is characteristic of ongoing construction, contradiction, and reconstruction, particularly in relation to the socially constructed model minority identity which depicts them as socially passive, politically obedient, and most importantly, having no or little racial inequality issues. To challenge media racism is to uncover the symbolic violence of media in reinforcing racial inequality and to reveal social agents' racialized habitus that is structured by and at the same time is structuring the field of power. To fight racism is to question the responsibility that the media take in constructing categorizations and distributing so-called information, facts and knowledge. It is to challenge the symbolic power of the media, a power of "world-making" (Bourdieu 1989: 22). It calls for efforts from all sides.

\section{REFERENCES}

Anderson, Benedict. 1983. Imagined Communities: Reflections on the Origin and Spread of Nationalism. London: Verso.

Anderson, Key. 1991. Vancouver's Chinatown: Racial Discourse in Canada, 1875-1980. Montreal \& Kingston: McGill-Queen's University Press.

Bourdieu, Pierre. 1977. Outline of a Theory of Practice. Cambridge: Cambridge University Press.

Bourdieu, Pierre. 1984. Distinction: A Social Critique of the Judgment of Taste. Cambridge, MA: Harvard University Press.

Bourdieu, Pierre. 1989. Social Space and Symbolic Power. Sociological Theory, 7 (1): 14-25.

Bourdieu, Pierre. 1990. The Logic of Practice. Cambridge: Polity Press.

Bourdieu, Pierre. 1991. Language and Symbolic Power. Cambridge: Polity Press.

Bourdieu, Pierre. 1998. On Television. London: Pluto.

Bourdieu, Pierre and Loïc J. D. Wacquant. 1992. An Invitation to Reflexive Sociology. Cambridge: Polity Press.

Charmaz, Kathy. 2005. Grounded Theory in the 21st Century: Applications for Advancing Social Justice Studies. In The Sage Handbook of Qualitative Research, $3^{\text {rd }}$ ed., edited by N. K. Denzin and Y. S. Lincoln, 507-536. Thousand Oaks, CA: Sage. 
Charmaz, Kathy. 2006. Constructing Grounded Theory: A Practical Guide through Qualitative Analysis. London, UK: Sage.

Cohen, Bernard. 1963. The Press and Foreign Policy. Princeton: Princeton University Press.

Cui, Dan. 2011. Two Multicultural Debates and the Lived Experiences of Chinese-Canadian Youth. Canadian Ethnic Studies 43/44(3-1): 123-143.

Cui, Dan. 2015. Capital, Distinction and Racialized Habitus: Immigrant Youth in the Fields of Canadian Schools. Journal of Youth Studies 18(9):11541169.

Cui, Dan. 2017a. Teachers' Racialised Habitus in School Knowledge Construction: A Bourdieusian Analysis of Social Inequality beyond Class. British Journal of Sociology of Education 38(8): 1152-1164.

Cui, Dan. 2017b. Transnationalism and Identification among Chinese Immigrant Youth: A Canadian Study. International Journal of Chinese Education 6(2): 156-173.

Cui, Dan., \& Kelly, Jennifer. 2013. “Too Asian?” or the Invisible Citizen on the Other Side of the Nation? The Journal of International Migration and Integration 14(1): 157-174.

Elizabeth, Devon. 2018. “'Crazy Rich Asians” Author Kevin Kwan Optioned his Book for only \$1.” Teen Vogue. August 21, 2018. https://www.teenvogue.com/story/crazy-rich-asians-author-kevin-kwan-optioned-bookone-dollar

Ericson, Richard, Patricia Baranek and Janet Chan. 1991. Representing Order: Crime, Law, and Justice in the News Media. Toronto: University of Toronto Press.

Fairclough, Norman. 2003. Analysing Discourse: Textual Analysis for Social Change. London: Routledge.

Findlay, Stephanie and Nicholas Köhler. 2010. “Too Asian?” Maclean's, 123 (45): 76-81. Academic Search Complete, EBSCOhost (accepted May 23, 2015).

Fiske, John. 1996. Opening the Hallway: Some Remarks on the Fertility of Stuart Hall's Contribution to Critical Theory. In Stuart Hall: Critical Dialogues in Cultural Studies, edited by D. Morley and K. Chen, 212-220. London and New York: Routledge.

Fleras. Augie. 2003. Media, Minorities and Multiculturalism. In Mass Media Communication in Canada, edited by A. Fleras, 278-309. Toronto: Thomson Nelson.

Fleras, Augie., and Jean. L. Elliott. 2007. Unequal Relation: An Introduction to Race, Ethnic and Aboriginal Dynamics in Canada. $5^{\text {th }}$ ed. Toronto: Pearson Education Canada. 
Grossberg, Lawrence. 1996. History, Politics and Postmodernism: Stuart Hall and Cultural Studies. In Stuart Hall: Critical Dialogues in Cultural Studies, edited by D. Morley and K. Chen, 151-173. London and New York: Routledge.

Henry, Frances., Carol Tator, Winston Mattis and Tim Rees. 2006. The Color of Democracy: Racism in Canadian Society. $3^{\text {rd }}$ ed. Toronto: Thomson Nelson.

Hier, Sean and Joshua Greenberg. 2002. Constructing a Discursive Crisis: Risk, Problematization and Illegal Chinese in Canada. Ethnic and Racial Studies 25 (3): 490-513.

Ho, Karen. K. 2018. "Crazy Rich Asians Is Going to Change Hollywood. It's About Time." Time, August 16, 2018. http://time.com/magazine/southpacific/5368960/august-27th-2018-vol-192-no-8-asia-south-pacific/

Jedwab, Jack. 2008. The Rise of the Unmeltable Canadians? Ethnic and National Belonging in Canada's Second Generation. Canadian Diversity 6(2): 2534.

Kelly, Jennifer. (1998). Under the gaze: Learning to be black in white society. Halifax: Fernwood Publishing.

Lah, Kyung. 2011. "Plastic Surgery Boom as Asians Seek 'western' Look." CNN, May 23. http://www.cnn.com/2011/WORLD/asiapcf/05/19/korea. beauty/

Lareau, Annette, Shani Adia Evans, and April Yee. 2016. The Rules of the Game and the Uncertain Transmission of Advantage: Middle-class Parents' Search for an Urban Kindergarten. Sociology of Education 89(4): 279 299.

Lee, Robert G.1999. Orientals: Asian Americans in Popular Culture. Philadelphia: Temple University Press.

Lehmann, Wolfgang. 2012. Working-class students, habitus, and the development of student roles: a Canadian case study. British Journal of Sociology of Education 33(4): 527-546.

Li, Peter S. 1994. Unneighbourly Houses or Unwelcome Chinese: The Social Construction of Race in the Battle over "Monster Homes" in Vancouver. International Journal of Comparative Race and Ethnic Studies 1(1): 4766.

Li, Peter S. 1998. The Chinese in Canada. $2^{\text {nd }}$ ed. Toronto, Oxford and New York: Oxford University Press.

Li, Peter S. 2003. The Place of Immigrants: The Politics of Difference in Territorial and Social Space. Canadian Ethnic Studies 35 (2): 1-13.

Mahtani, Minelle. 2008. Racializing the Audience: Immigrant Perceptions of Mainstream Canadian English-Language TV News. Canadian Journal of Communication 33 (4): 639-660. 
Morse, Janice M. 2007. Sampling in Grounded Theory. In The Sage Handbook of Grounded Theory, edited by Antony Bryant and Kathy Charmaz, 229244. Los Angeles, CA: Sage.

"Olympic Nightmare: the China Problem", South Park Studios. http://southpark. cc.com/clips/187263/olympic-nightmare

Park, Hijin. 2011. Being Canada's National Citizen: Difference and the Economics of Multicultural Nationalism. Social Identities: Journal for the Study of Race, Nation and Culture 17 (5): 643-663.

Patton, Michael. 2002. Qualitative Research and Evaluation Methods. Thousands Oaks, CA: Sage Publications.

Pfzelzer, Jean. 2007. Driven Out: The Forgotten War against Chinese Americans. Berkeley: University of California Press.

Reay, Diane. 2002. Shaun's Story: Troubling Discourses of White WorkingClass Masculinities, Gender and Education 14(3): 221-234.

"Recognizing Adolescence," World Health Organization online. Last modified 2014, http://apps.who.int/adolescent/second-decade/section2/page1/recognizing-adolescence.html

Reitz, Jeffrey. and Rupa Banerjee. 2007. Racial Inequality, Social Cohesion, and Policy Issues in Canada. In Belonging? Diversity, Recognition and Shared Citizenship in Canada, edited by K. Banting, T. Courchene and F. L, 489-545. Seidle, Montreal: Institute for Research on Public Policy.

Richardson, John. 2007. Analysing Newspaper: An Approach from Critical Discourse Analysis. New York: Palgrave Macmillan.

Said, Edward. 1978. Orientalism. New York: Vintage.

Schubert, Daniel. 2008. Suffering/Symbolic Violence. In Pierre Bourdieu: Key concepts, edited by M. Grenfell, 183-198. Durham, UK: Acumen.

Stanley, Timothy. 2011. Contesting White Supremacy: School Segregation, Antiracism, and the Making of Chinese Canadians. Vancouver: UBC Press.

Sun, Rebecca. 2015. “'Crazy Rich Asians' Author Kevin Kwan: 'Why does Hollywood Think We'd Want to See this Movie with White People?"' The Hollywood Reporter, June 26, 2015. https://www.hollywoodreporter. com/bookmark/crazy-rich-asians-author-kevin-kwan-why-does-hollywood-think-we-d-want-see-movie-white-people-804381

Swartz, David. 1997. Culture and Power: The Sociology of Pierre Bourdieu. Chicago: University of Chicago Press.

Thomas, W. I. and D. S. Thomas. 1928. The Child in America: Behaviour Problems and Programs. New York: Knopf.

Thomson, Pat. 2008. Field. In Pierre Bourdieu: Key concepts, edited by M. Grenfell, 67-81. Durham, UK: Acumen.

van Dijk, Teun. 1991. Racism and the Press. London: Routledge. 
Wallace, Derron. 2018. Cultural capital as whiteness? Examining logics of ethno-racial representation and resistance. British Journal of Sociology of Education 39(4): 466-482.

Wang, Lihshing. 2008. Myths and Realities of Asian American Success: Reassessing and Redefining the 'Model Minority' Stereotype. In Model Minority Myth Revisited: An Interdisciplinary Approach to Demystifying Asian American Educational Experiences, edited by Guofang Li and Lihshing Wang, 21-42. Charlotte: Information Age.

Wilkinson, Lori. 2008. Visualizing Canada, Identity and Sense of Belonging among Second GenerationYouth in Winnipeg. Canadian Diversity 6(2): 84-86.

\section{Acknowledgements}

- $\quad$ This work was supported by the Social Sciences and Humanities Research Council of Canada (SSHRC)

- $\quad$ Postdoctoral Fellowship [grant number [756-2015-0566], sponsored by the Graduate School of Education at the University of California Berkeley.

Dan Cui is an Assistant Professor in the Department of Child and Youth Studies at Brock University. She received her PhD degree from the University of Alberta and held a SSHRC Postdoctoral Fellowship at the University of California Berkeley. Her research interests include sociology of education, sociology of children and youth, immigration, integration and transnationalism, intersectionality of race, class and gender, social justice and equity studies, and qualitative research methods.

Email: dcui@brocku.ca

Frank C. Worrell is a Professor at the University of California, Berkeley where he serves as Faculty Director of the School Psychology Program, the Academic Talent Development Program, and the California College Preparatory Academy. His areas of expertise include at-risk youth, cultural identities, scale development, talent development/gifted education, time perspective, and the translation of psychological research into practice. Dr. Worrell is a Fellow of the American Educational Research Association, the Association for Psychological Science, and the American Psychological Association, and a recipient of National Association for Gifted Children's Distinguished Scholar Award. He is also a member of the National Academy of Education.

Email: frankc@berkeley.edu 